\title{
Practicum Teachers' Use of Mobile Technology as Measured by the Technology Acceptance Model
}

\begin{abstract}
This study utilised the Technology Acceptance Model (TAM) to examine practicum teachers' current use of mobile technology and their intentions of use in the future. A survey was conducted to better understand the relationship between practicum teachers and their potential assimilation of technology into classroom practice. The survey questionnaire was administered to 100 undergraduate students at [institute withheld], [country withheld]'s teacher preparatory university. The following four key constructs of the TAM were assessed: perceived ease of use (PEU), perceived usefulness (PU), subjective norm (SN), and behavioural intention to use (BIU). The impact of practicum teachers' gender and academic subjects on their acceptance of technology were also investigated. The present study found strong links between PEU and PU. While practicum teachers perceived mobile technology as being useful and intended to use it in their classrooms, BIU was not significantly impacted by PEU, PU, or SN. The data also suggested that gender did not affect BIU while practicum teachers' academic subjects might be an indicator of their future intentions to use mobile technology. With these findings, recommendations are made to further improve the integration of mobile technology in classroom practice.
\end{abstract}

Keywords: Technology Acceptance Model, practicum teachers, mobile technology, gender, academic subjects

\section{Introduction}

\section{Role of Technology in Practicum Teachers' Education}

In 2017, Singaporeans spent an average of seven hours on the internet daily-ranking 13th globally-with $95 \%$ of the active internet users using mobile devices to access the internet (We Are Social, 2018). The rapid evolution and spread of mobile technology over the past decade has led to the [country withheld] Ministry of Education (MOE) and [institute withheld] jointly creating a multitude of technological, pedagogical and content-driven resources to supplement and revamp classroom learning (Divaharan, Lim \& Tan, 2011; Jung, 2005; Looi, Hung, Bopry, \& Koh, 2004). As the integration of technology has often been 
considered a crucial factor in the improvement of teaching and learning, one of the local initiatives include the construction of Information and Communications Technology (ICT) facilities in school to support teachers.

For maximal utilisation of technology resources, the educational systems of many countries require practicum teachers to undertake computer literacy courses while fulfilling the requirements for a teaching credential (Jung, 2005; Yildirim, 2000). Similarly, during preservice training at [institute withheld], it is necessary for practicum teachers to have appropriate technological practice to prepare them for the course of their teaching career. As such, a 12-week computer-specific course, ICT in Meaningful Learning, is offered to equip practicum teachers with ICT-related pedagogical skills. This course facilitates practicum teachers' engagement of students in quality and meaningful learning in the 21 st century by focusing on making links between ICT and the five dimensions of meaningful learning: (a) engaging prior knowledge; (b) learning by doing; (c) real-world context; (d) collaborative learning; and (e) self-directed learning. In this course, practicum teachers learn how to apply their preferred ICT tools to design a technology-enabled lesson for a topic based on their academic subjects of choice (Koh, Woo, \& Lim, 2013).

Despite dramatic developments in mobile technology over the previous three decades, educators remain sceptical about its usage in classroom practice (D'Agostino, Rodgers, Harmey, \& Brownfield, 2016; Ertmer \& Ottenbreit-Leftwich, 2010; Gray, Thomas, \& Lewis, 2010; Herold, 2015; UNESCO, 2012). In order to implement ICT effectively, it is important to clearly identify the objectives of the lesson and establish classroom technological rules (Hashemi, Azizinezhad, Najafi, \& Nesari, 2011; Zielezinski, 2016). McClanahan (2017) noted that after receiving appropriate training, "the teacher candidates were clearly beginning to grasp the idea that we were not using the technology for the sake of technology but to find the most productive way to teach content" (p. 20). However, due to the ubiquity of mobile 
technology, there have also been cases in which mobile technology has proven to be more harmful than beneficial in education and teachers can perceive it as a threat (Schmid, 2008; Mama \& Hennessy, 2013). The purpose of this study was to use the Technology Acceptance Model (TAM) to examine practicum teachers' acceptance of mobile technology in order to improve the way future teachers are prepared to utilise digital tools in the classroom.

\section{Background}

\section{Definition of Mobile Technology}

The ongoing transition to mobile technology in classroom practices (also referred to as mobile learning or m-learning) caters to the needs of learners in the 21 st century (Ally \& Tsinakos, 2014; Gerstein, 2013). This shift in ICT pedagogical skills can be provided through the creation of active learning strategies that allow students to learn in their own waysresulting in higher order thinking (Cochrane, 2013; Stoerger, 2013). According to Quinn (2000) and Geddes (2004), mobile learning and electronic learning (e-learning) are used to acquire knowledge and skills that can be accessed anytime and anywhere, with wellsupported and productive interaction and performance-based assessment. Stevens and Kitchenham (2011) also describe mobile learning as "meaningful learning that occurs through the use of wireless handheld devices such as the cell phone, personal digital assistant, mini-computer, or iPod" (p. 3). For the purposes of this study, the term mobile technology is defined as iPads, smartphones, notebooks, and handheld devices.

\section{Transition to Technology When Learning}

Many professions have evolved to incorporate the usage of mobile devices, including healthcare (Nasi, Cucciniello, \& Guerrazzi, 2015; Kalem \& Turhan, 2015), agriculture (Lightfoot, Gillman, Scheuermeier, \& Nyimbo, 2008; Qiang, Kuek, Dymond, \& Esselaar, 
2012), and banking (Jenkins, 2008; Tiwari, Buse, \& Herstatt, 2006). Unfortunately, teachers and students have not kept pace with the ongoing digital revolution (Buckingham, 2007; Norris \& Soloway, 2015). As early as 1992, Perkins emphasized that practicum teachers may not be sufficiently equipped to face the challenges of the next century. An extensive amount of literature indicates that the stumbling block teachers face in using mobile technology is the inadequate technological teaching they receive in their initial teachers' preparatory programs (Beaver, 1992; Brooks \& Kopp, 1989; Selwyn, 2007; Yaghi, 1997; Yildirim \& Kiraz, 1999). Instead of utilising technology as a medium to develop important skills such as critical thinking in students, many teachers only explore technology during their training through the safest and most traditional approaches.

\section{Introduction of ICT Masterplan}

Researchers worldwide have determined that the advancement of mobile technology, its usage in classroom practices, and transformed pedagogical skills and techniques are required to heighten students' learning experiences and help them develop "21st century skills" (Swallow, 2017, p. 154). [country withheld]'s MOE has begun to act on this, aiming to empower "Future-ready and Responsible Digital Learners" (Ministry of Education (MOE), n.d., para. 1) by expanding their subject proficiency in relation to what MOE has termed "21st Century Competencies" (para. 1) in its recent Masterplan 4 for ICT in Education. Successful implementation of Masterplan 4 requires enthusiastic support from teachers as the architects of classroom practices and experiences, and school leaders as the cultivators for ICT usage in schools (MOE, n.d.). However, some researchers have found that opinions diverge on the effectiveness and appropriateness of mobile technology, at times resulting in a lack of "widespread teacher change" (Gunn \& Hollingsworth, 2013, p. 204). Therefore, it is imperative that MOE is armed with all necessary and relevant data from studies of 
technology acceptance in education for the successful enacting of effective systemic changes.

\section{Advantages of Mobile Technology Usage in Education}

The advantages of mobile learning are manifold. Content is easily accessible as mobile devices are portable and lightweight and do not occupy much space in the classroom, unlike desktop computers. Students are also motivated to practice the ownership of and commit to using and learning from mobile devices (Hashemi et al., 2011). Little time is required to boot up mobile devices; thus, students have more time to engage and interact with their teachers and classmates productively. Furthermore, with the emphasis on interaction during classroom discussion, mobile learning has allowed students to work on their assignments collaboratively even though they have individual mobile devices (Sung, Chang, \& Liu, 2016).

The MOE pointed out in Masterplan 4 that "teachers [are the] Designers of Learning Experiences and Environments" (MOE, n.d., para. 2) that utilise mobile technology in various ways, such as accessing documents, quizzes, feedback sessions, self-assessment tools, video clips, photo albums, and audio libraries. Moreover, mobile learning enables teachers to use online platforms for lecture archives and adopt flipped classroom pedagogies. Additionally, many teachers have made use of mobile learning to exhibit students' effort and work, providing them with feedback, recognition, and mutual learning opportunities.

\section{Practicum Teachers' Acceptance of Technology}

Nonetheless, in spite of current efforts to prepare practicum teachers to use mobile technology, research has revealed that many teachers remain uncertain and hesitate to adopt it in their classroom practices. Although teachers' attitudes toward mobile technology have a significant impact on their teaching and their students (Alvarez, Brown, \& Nussbaum, 2011), various studies conducted on the integration of technology have found that practicum teachers' uncertainties are due to their doubts regarding the effectiveness of the ICT training 
in their initial teachers' preparatory program (Karchmer, 2001; Stolle, 2007). In contrast, Simonson (1995) asserted that having a positive attitude in the learning process encourages performance and accomplishment while McClanahan (2017) emphasized that "it is critical that teacher candidates become conversant with the innovative curricular use of digital technology before they are launched on their teaching careers" (pp. 15-16, emphasis in original). To increase mobile learning acceptance, practicum teachers and teacher preparatory institutes should be made explicitly aware of these findings.

\section{The Technology Acceptance Model}

In order to gauge practicum teacher attitudes towards technology, the TAM was adopted in this study. The TAM is a theoretical approach that models the process of acceptance and usage of a new technology by a diverse group of people (Davis, Bagozzi, \& Warshaw, 1989), and was one of the first models to include cognitive factors that affect technology acceptance across an array of occupations, according to Davis (1989). The TAM was originally based on the theory of reasoned action, designed by Fishbein and Ajzen (1975) to analyse and anticipate behavioural intentions and predict people's actual behaviour based on factors such as attitudes and subjective norms, the latter of which refers to beliefs without motivation to comply. Table 1 displays the definitions of the adapted TAM.

[Table 1 near here]

As stated by Davis and his colleagues in 1989 (Davis et al., 1989), the initial version of the TAM posited that a person's behavioural intentions to use a technology (BIU) is influenced by their positive or negative attitudes toward its usage (AU). AU can be established through the technology's perceived usefulness (PU) and perceived ease of use (PEU), which attribute the individual's usage of technology to its anticipated effectiveness 
and the minimum effort for the user, respectively. PU and PEU thus indirectly affect BIU for technology usage.

In the extensive research that has been conducted on the initial TAM, multiple studies have concluded that external variables such as social influences (subjective norm) also affect the attitudes of individuals (Legris, Ingham, \& Collerette, 2003; Venkatesh \& Bala, 2008). These authors state that the existence of these external variables affect PU and PEU, thus influencing the actual behaviour of the individual. In addition, PEU has a direct impact on PU; see Figure 1 for a comprehensive diagram of these constructs.

[Figure 1 near here]

According to Stevens and Kitchenham (2011), there is empirical support for the TAM being a credible and accurate indicator of the acceptance of mobile technology, especially in the field of education where pre-service and in-service teachers are introduced to mobile technology that can be incorporated during lessons. However, very little research has been done to measure practicum teachers' attitudes and usage. In this study, the TAM served as a framework to understand and make predictions about whether practicum teachers believe mobile learning can be assimilated into their daily classroom practice systems.

\section{TAM in Education: Local Findings}

Teo (2012b) supplemented the TAM by adding two new constructs to the TAM in education: facilitating conditions (FC) and subjective norm (SN). FC refers to the training in schools and the administrative assistance that can improve practicum teachers' perceptions of the ease of use of mobile technology, while SN refers to the strength of any external pressure regarding practicum teachers' usage of mobile technology and its accompanying effects on their behaviour (see Table 1). 
Despite the addition of two new factors to the TAM, Teo (2012a) found that AU has the largest effect on BIU. Practicum teachers were reported to have positive responses and attitudes (AU) toward mobile learning, including the belief that mobile learning would enhance their work performance as well as increase their teaching efficacy (PU). Thus, it is possible that practicum teachers are inclined to use technology in their classroom practices given the right circumstances.

MOE's 2015 Masterplan 4 for ICT in Education aims to engender consistency in the attitudes of school leaders, colleagues, and practicum teachers regarding the inclusion of mobile technology in the classroom. School leaders play a crucial role in nurturing students' technological ability by setting clear objectives for each lesson, implementing positive learning environments, and establishing technological infrastructures in schools (FC and $\mathrm{SN}$ ). Thus, the environments that school leaders provide in schools, including [institute withheld] where practicum teachers undergo their initial teachers' preparatory program, will influence the attitudes and motivations of pre-service and in-service teachers.

\section{Study Aim}

The purpose of this study was to examine practicum teachers' acceptance of mobile technology based on their PEU, PU, SN, and BIU. Four hypotheses from Teo's (2012a, 2012b) adapted TAM were tested:

(1) PEU has an effect on PU.

(2) PEU has an effect on BIU.

(3) PU has an effect on BIU.

(4) SN has an effect on BIU.

In many cases, practicum teachers' apprehension toward the use of mobile learning might be due to underlying factors such as their age, gender, and academic subjects (Wang, Wu, \& 
Wang, 2009). This study used demographic information to discover whether differences in the gender and academic subjects of practicum teachers impacted teachers' technology acceptance, measured in terms of the TAM constructs. By investigating practicum teachers' assessments of the practicality and feasibility of the transition to mobile technology before they officially introduced it to their students during classroom practice, this study can be considered a critical perspective on mobile technology's ability to encourage the development of classroom practices and empower students in their learning.

\section{Methodology}

\section{Participants}

The participants in this research study were 100 practicum teachers enrolled in [institute withheld]. Information such as the age, gender and academic subjects of each practicum teacher is presented in Table 2. Among the practicum teachers, 74 were females and 26 were males, with the mean age of the practicum teachers being 22.46 years old $(\mathrm{SD}=3.75)$.

\section{Procedure}

A non-incentivised online survey questionnaire delivered via Google Forms was made available to practicum teachers through word-of-mouth and messaging platforms such as WhatsApp broadcast and emails. Before starting the survey, practicum teachers were briefed on the purpose of the study, assured that their participation was voluntary, and informed that they could withdraw from participation at any time. On average, each teacher took approximately 10 minutes to complete the online survey questionnaire.

\section{Instrument}

The survey questionnaire consisted of two distinct sections: one measuring demographics and 
one measuring the four constructs of the TAM. These constructs were Behavioural Intention to Use (BIU - 1 item), Perceived Usefulness (PU - 4 items), Perceived Ease of Use (PEU - 4 items), and Subjective Norms (SN - 2 items). Practicum teachers responded to each item on a 5-point Likert scale of strongly agree (1), agree (2), neither agree nor disagree (3), disagree (4), and strongly disagree (5). The scores from each item per construct were aggregated to provide individual scores. In addition, practicum teachers' qualitative examples of usage of mobile learning in classroom practices were also recorded in the open-ended section of the survey questionnaire (see Appendix for the questionnaire).

\section{Data Analysis}

The data collected from the respondents were analysed using SPSS 24.0. The analysis involved descriptive statistics, a Mann-Whitney U test (a non-parametric test) with gender as the independent variable and BIU, PU, PEU, and SN as the dependent variables, and linear regression where the independent variables of PU, PEU, and SN were tested against the dependent variable of BIU. Descriptive statistics were used to analyse the frequency and percentages of the practicum teachers' demographics while the Mann-Whitney U test and linear regression were used to compare the variables to the practicum teachers' usage of mobile learning.

\section{Results}

\section{Descriptive Statistics on BIU, PU, PEU and SN}

The descriptive statistics for the four constructs are shown in Table 3. The means for all constructs range from 2.19 to 2.78 which indicates that most practicum teachers had generally positive perceptions regarding the usage of mobile learning in their classroom practices, along with the perception of organisational acceptance and encouragement of 
mobile learning in the classroom. The standard deviations range from 0.87 to 1.03 which also shows a narrower spread around the mean.

[Table 3 near here]

\section{Mann-Whitney U Test on Gender for BIU, PU, PEU and SN}

The Mann-Whitney U test is a nonparametric test that was performed on gender as the independent variable against the dependent variables of BIU, PU, PEU, and SN. Results are presented in Tables 4 and 5.

[Table 4 near here]

[Table 5 near here]

The results revealed that there were no significant differences between gender for the four dependent variables of BIU $(\mathrm{Z}=-1.139 ; \mathrm{p}=.255>.05), \mathrm{PU}(\mathrm{Z}=-.119 ; \mathrm{p}=.906>.05)$, $\operatorname{PEU}(\mathrm{Z}=-.406, \mathrm{p}=.685>.05)$ and $\mathrm{SN}(\mathrm{Z}=-1.735, \mathrm{p}=.083>.05)$ at the level of $\mathrm{p}<.05$. These results suggest that practicum teachers' acceptance of mobile learning does not differ between genders.

\section{Linear Regression on Hypotheses}

After conducting linear regression analyses, the impact of PEU on PU was found to have an $\mathrm{R}^{2}$ value of .6222, while PEU, PU, and SN have $\mathrm{R}^{2}$ values of $0.157, .0568$, and .0219 as predictors of BIU, respectively. Thus, out of our four hypotheses, only the hypothesis that PEU affects PU was supported by the data. Table 6 shows the summary of the relationships between the variables that were tested. It is clear that ease of use is critical to how much we think we may use mobile technology but not necessarily on our intent to use it.

[Table 6 near here]

\section{Discussion}

In this study, it was found that most teachers accepted mobile technology in classroom 
practices as the mean BIU score was under 3, indicating agreement or strong agreement. This suggests that practicum teachers will use mobile learning in their future classroom practice. The confidence felt by the teachers may be the result of ICT-based modules in the teachers' preparatory programs that trained practicum teachers to utilise technology in classrooms (Koh et al., 2013) and supported them with a positive and conducive environment-a case of an FC successfully increasing BIU. Moreover, with MOE's 2015 Masterplan 4 initiative, practicum teachers have been made well aware of the importance of and the organizational focus on cultivating the usage of mobile learning in classroom practices-another example of FC and SN increasing BIU. Finally, the high level of internet usage in Singapore (We Are Social, 2018) could be habituating [nationality withheld] pre-service teachers to the use of mobile technology in all aspects of their lives, including classroom practice.

With regard to the relationship between gender and the four constructs of the TAM investigated, no significant difference was found between genders. Potential contributing factors could be the small male sample size $(n=26)$, leading to less valid measurements of male attitudes towards technology, or cohort effects due to the participants' youth $(\mathrm{M}=22.46$ years, $\mathrm{SD}=3.75)$, resulting in relatively homogeneous perceptions of technology across genders as societal perceptions of technology and gender issues evolve with time. In 2002, North and Noyes suggested that the higher frequency of computer usage in schools for teaching and learning could prevent gender differences from developing, which could apply to mobile technology as well.

This result does not support research which indicates that gender plays an important role in the acceptance of technology, and adds to the multitude of studies that have not produced uniform conclusions. For example, Venkatesh and Morris found in 2000 that men value PU more while women are more influenced by PEU and SN. In contrast, Broos (2005) concluded that men have more positive attitudes toward the use of new ICT than women, 
whereas Teo (2008) did not find gender differences in the computer attitudes of preservice teachers. On the other hand, Teo, Fan, and Du (2015) found that PEU seemed to have varied effects across genders, with women being more affected than men. More research needs to be done on investigating the effect of gender on the TAM constructs.

This study also produced anecdotal evidence that practicum teachers who majored in different academic subjects differed in their acceptance of technology, which supports Teo's findings in 2008 that preservice teachers' academic subjects significantly affected their attitudes toward technology usage in classrooms. Despite most practicum teachers' positive attitudes towards technology, eight teachers indicated they thought that mobile learning was potentially less effective than their current methods, though they would likely still use mobile technology in their classroom practices. Teacher 75 (a male Mathematics and Physics teacher) even claimed, "I would actually avoid using it as far as possible as it may result as a distraction to the students [sic]", while Teacher 12 (a female Music and English Language teacher) stated:

\footnotetext{
In my opinion, the use of mobile technology may not be fully necessary in my music lessons as I am able to use real instruments to make music. However, being able to use the mobile applications through iPads and mobile phones allow students to listen and play specific instruments of other cultures (e.g. African instruments) that are not available in the music room. In addition, in context to pop band music, with apps such as garageband, people are able to create music without necessarily having the experience in playing specific instruments [sic].
}

At the same time, Teacher 23 (a female Art teacher) wrote, “I don't think I will! I would need to get students routinized before introducing this to them [sic]" while Teacher 92 (a female English and Social Studies teacher) shared, "I'm not sure yet to be honest, at this point in time I don't see many benefits, but I'm open to the idea and I'm willing to try it if it'll help my students." The teachers' lack of unanimous support for mobile learning echoes 
the findings of a study by Sutherland et al. (2004) in which practicum teachers had their reservations when it came to incorporating mobile learning in classroom practices but were willing to give it a try to enhance their students' learning.

Based on the mean value of PU, most practicum teachers perceived mobile learning as being useful. Many practicum teachers who showed positive attitudes toward the usage of mobile learning gave numerous examples of using tools such as interactive quizzes and online mind-maps. However, teachers did not necessarily intend to use mobile learning in their classroom practices as BIU was not significantly supported by PU, which contradicts the findings from previous studies. This might be due to practicum teachers' perceptions that their schools might not have many mobile technology resources available to them once they start teaching or their perceptions of mobile technology's differing suitability for students, especially with regard to their age. As mentioned by Teacher 38 (a female Mathematics and English Language teacher), “I don't think it will be effective to use mobile devices for teaching specifically as I will be teaching the primary school level and will serve as a distraction more than a supportive tool [sic]." The findings from this study join past research in stating that practicum teachers think engaging in mobile learning in classroom practice is a double-edged sword (McGrail, 2006; Shoffner, 2009).

In addition, the analysis showed that PEU affected PU which, in combination with the lack of effect of PU on BIU, could account for the lack of effect of PEU on BIU. While practicum teachers thought that mobile learning was easy to use and thus found it useful in their classroom practices, negative attitudes could have affected their intentions to use mobile learning in classrooms. Yildirim (2000) suggests that teachers with negative attitudes toward a new technology will not be able to teach students using that technology, thus discouraging its use in classrooms. Other possible factors that influenced the BIU of practicum teachers could include FC such as [country withheld]'s MOE ICT Masterplans over the years and the 
spread of compulsory mobile learning in schools, which would have decreased the relative impact of PEU and PU on BIU.

Lastly, SN was not found to have a significant effect on the usage of mobile learning in classroom practices for practicum teachers. Since they were still teachers in training, there was a lack of hierarchical authority in [institute withheld] that compelled them to use mobile learning. Moreover, many practicum teachers had not used mobile learning in an actual classroom environment as they were not required to use mobile learning; most used Microsoft Word and Microsoft PowerPoint to do their assignments. It is possible that once practicum teachers emerge from their training and take on their permanent postings, their BIU to use mobile technology in classroom practice will increase, especially if their schools prioritise and support its usage.

\section{Implications for Practice}

This study found that [institute withheld] preservice teachers are generally positive about and open to mobile learning. However, based on the qualitative data collected, MOE's Masterplan 4 and [institute withheld]'s teacher preparatory programs must sustain and scale up their initiatives to further increase future service teachers' usage of mobile learning in classrooms. One of the means towards this end would be the improvement of technical support systems in schools to enhance the FC for mobile learning, as this factor might have a larger impact on BIU than PU and PEU.

Next, greater effort needs to be put into helping preservice and current teachers explore different ways of effectively using mobile technology in their classrooms, including more relevant and useful mobile technology apps and activity types that are differentiated to suit multiple learner ages. The comment made by Teacher 38 about the unsuitability of mobile learning usage in primary classrooms is evidence of practicum teachers not having yet 
been adequately exposed to classroom uses of mobile technology for learners of all ages. Only with adequate technical and pedagogical support will teachers be able to make fair evaluations of the usefulness of mobile learning.

Further, mobile learning should be made compulsory for practicum teachers but, and this is critical, the learning needs to be practical and contextual for the environment in which the practicum teacher will teach. Mobile technology currently being an optional tool for practicum teachers during their training has a two-fold impact on teachers: Crucially, it is a signal that mobile learning is not strongly valued by the leadership, resulting in less incentive for preservice teachers to adopt mobile learning. This perpetuates the second detrimental effect of mobile technology's optional status in teacher preparatory programs-that of preservice teachers remaining insufficiently familiar and comfortable using mobile learning in classroom practice, which naturally leads to a low frequency of mobile learning usage when they become service teachers.

Finally, institutes of teacher preparation must recognize that teacher attitudes are more important than technical skills when integrating mobile technology. While exposure to various applications of mobile technology in classroom practice can be highly beneficial, the key to becoming a 21 st century educator is the ability to see the potential of various technologies and tools for improving their students' learning, as well as the resilience to persevere even if their attempts to incorporate new technology into their lessons are not immediately successful. Teachers must be open to experimenting and continuously developing as educators throughout their entire careers, which is an attitude that must be fostered during their initial preparatory training.

\section{Limitations}

As with any research, there are limitations in this study. Firstly, the data collected for this 
research study were self-reported which leads to common method variance, with the independent and dependent variables being collected at the same time and thus resulting in potential inaccuracies. Secondly, the data were collected using a cross-sectional and single administered survey questionnaire that might not have captured participants' complete attitudes toward and acceptance of mobile learning. Lastly, while the TAM is a valuable guide for exploring practicum teachers' acceptance of mobile learning in classroom practice, as mobile technology-and thus mobile learning-evolves, the external factors that influence practicum teachers' usage of mobile learning will continue to change. Factors such as the accessibility of Wi-Fi and the availability of technological resources in the school environment will have a large impact on teacher attitudes. It is possible that further adaptation of the TAM is necessary for it to continue being a useful framework for the investigation of technology acceptance, especially given the rapid technological advances currently occurring.

\section{Further Research}

To address the cross-sectional nature of this study and possible cohort effects encountered, longitudinal surveys could be conducted on teachers as they progress from pre-service to inservice to obtain a more accurate depiction of their attitudes toward mobile learning usage. Further studies could also be conducted on the effect of gender on technological acceptance, especially on younger segments of the population as contemporary attitudes toward technology might have evolved in parallel with technology. A third avenue for more in-depth investigation is the effect that teachers' academic subjects have on their attitudes and technological acceptance, given the lack of consensus in the literature at present. Finally, the construct of facilitating conditions should be investigated with reference to practicum teachers' BIU. With the currently rapid pace of technological evolution, the range of possible 
external facilitating factors constantly increases, potentially increasing FC's impact on BIU.

\section{Conclusion}

Research has shown that mobile technology has the potential to improve students' learning. This study found that practicum teachers in [country withheld] were positive about mobile learning and its usefulness, but remained uncertain about ease of use when managing students and experienced low external expectations of its use in a classroom setting. Weak links were discovered between practicum teachers' intentions to use mobile technology in classrooms and its perceived ease of use, its perceived usefulness, and the subjective norm in favour of mobile learning. The authors of this study hope that additional technical, pedagogical, and leadership support will further improve practicum teachers' acceptance of mobile learning in classroom practice.

\section{Acknowledgements}

No potential conflict of interest was reported by the authors, and no funding was received for this research.

\section{References}

Ally, M., \& Tsinakos, A. (2014). Introduction: Enhancing access to education with mobile learning. In M. Ally \& A. Tsinakos (Eds.), Increasing access through mobile learning (pp. 1-4). Vancouver, BC: Commonwealth of Learning and Athabasca University. Alvarez, C., Brown, C., \& Nussbaum, M. (2011). Comparative study of netbooks and tablet PCs for fostering face-to-face collaborative learning. Computers in Human Behavior, 27(2), 834-844.

Beaver, J. W. (1992). Training teachers to organize and design computer and video projects.

In D. Carey, R. Carey, D. Willis \& J. Willis (Eds.), Technology and Teacher Education Annual-1992 (pp. 285-288). Charlottesville, VA: Association for the Advancement of Computing in Education.

Brooks, D. M., \& Kopp, T. W. (1989). Technology in teacher education. Journal of Teacher Education, 40(4), 2-8. 
Broos, A. (2005). Gender and information and communication technologies (ICT) anxiety: Male self-assurance and female hesitation. CyberPsychology \& Behavior, 8(1), 2131.

Buckingham, D. (2007). Beyond technology: Children's learning in the age of digital culture. Cambridge, UK: Polity Press.

Cochrane, T. (2013). M-learning as a catalyst for pedagogical change. In Z. L. Berge \& L. Y. Muilenberg (Eds.), Handbook of mobile learning (pp. 620-647). New York, NY: Routledge.

D’Agostino, J. V., Rodgers, E., Harmey, S., \& Brownfield, K. (2016). Introducing an iPad app into literacy instruction for struggling readers: Teacher perceptions and student outcomes. Journal of Early Childhood Literacy, 16(4), 522-548.

Davis, F. D. (1986). A technology acceptance model for empirically testing new end-user information systems: Theory and results (Doctoral dissertation). Massachusetts Institute of Technology: Cambridge, MA. Retrieved from http://hdl.handle.net/1721.1/15192

Davis, F. D. (1989). Perceived usefulness, perceived ease of use, and user acceptance of information technology. MIS Quarterly, 13(3), 319-340.

Davis, F. D., Bagozzi, R. P., \& Warshaw, P. R. (1989). User acceptance of computer technology: A comparison of two theoretical models. Management Science, 35(8), 982-1003.

Divaharan, S., Lim, W., \& Tan, S. (2011). Walk the talk: Immersing pre-service teachers in the learning of ICT tools for knowledge creation. Australasian Journal of Educational Technology, 27(8), 1304-1318.

Ertmer, P. A., \& Ottenbreit-Leftwich, A. T. (2010). Teacher technology change: How knowledge, confidence, beliefs, and culture intersect. Journal of Research on Technology in Education, 42(3), 255-284.

Fishbein, M., \& Ajzen, I. (1975). Belief, attitude, intention, and behavior: An introduction to theory and research. Reading, MA: Addison-Wesley.

Francis, L. J. (1994). The relationship between computer related attitudes and gender stereotyping of computer use. Computers and Education, 22(4), 283-289.

Geddes, S. J. (2004). Mobile learning in the 21st century: Benefit for learners. Knowledge Tree, 30(3), 214-228. 
Gerstein, J. (2013). Team and community building using mobile devices. In Z. L. Berge \& L. Y. Muilenberg (Eds.), Handbook of mobile learning (pp. 667-699). New York, NY: Routledge.

Gray, L., Thomas, N., and Lewis, L. (2010). Teachers' use of educational technology in U.S. Public Schools: 2009 (NCES 2010-040). Washington, DC: National Center for Education Statistics, Institute of Education Sciences, U.S. Department of Education. Gunn, T. M., \& Hollingsworth, M. (2013). The implementation and assessment of a shared 21st century learning vision: A district-based approach. Journal of Research on Technology in Education, 45(3), 201-228.

Hashemi, M., Azizinezhad, M., Najafi, V., \& Nesari, A. J. (2011). What is mobile learning? Challenges and capabilities. Procedia - Social and Behavioral Sciences, 30, 24772481.

Herold, B. (2015, June 10). Why Ed Tech is not transforming how teachers teach. Education Week. Retrieved from https://www.edweek.org/ew/articles/2015/06/11/why-ed-techis-not-transforming-how.html

Jenkins, B. (2008). Developing mobile money ecosystems. Washington, DC: IFC and the Harvard Kennedy School.

Jung, I. (2005). ICT-pedagogy integration in teacher training: Application cases worldwide. Journal of Educational Technology \& Society, 8(2), 94-101.

Kalem, G., \& Turhan, C. (2015). Mobile technology applications in the healthcare industry for disease management and wellness. Procedia - Social and Behavioral Sciences, 195, 2014-2018.

Karchmer, R. A. (2001). The journey ahead: Thirteen teachers report how the internet influences literacy and literacy instruction in their K-12 classrooms. Reading Research Quarterly, 36(4), 442-466.

Koh, J. H. L., Woo, H., \& Lim, W. (2013). Understanding the relationship between Singapore preservice teachers' ICT course experiences and technological pedagogical content knowledge (TPACK) through ICT course evaluation. Educational Assessment, Evaluation and Accountability, 25(4), 321-339.

Legris, P., Ingham, J., \& Collerette, P. (2003). Why do people use information technology? A critical review of the technology acceptance model. Information \& Management, 40(3), 191-204.

Lightfoot, C., Gillman, H., Scheuermeier, U., \& Nyimbo, V. (2008). The First Mile Project in Tanzania. Mountain Research and Development, 28(1), 13-17. 
Looi, C., Hung, D., Bopry, J., \& Koh, T. (2004). Singapore's Learning Sciences Lab: Seeking transformations in ICT-enabled pedagogy. Educational Technology Research and Development, 52(4), 91-99.

Mama, M., \& Hennessy, S. (2013). Developing a typology of teacher beliefs and practices concerning classroom use of ICT. Computers \& Education, 68, 380-387.

McClanahan, B. (2017). Transforming teacher education with digital technology: An informative journey. Delta Kappa Gamma Bulletin, 83(5), 15-23.

McGrail, E. (2006). "It's a double-edged sword, this technology business": Secondary English teachers' perspectives on a schoolwide laptop technology initiative. Teachers College Record, 108(6), 1055-1079.

Ministry of Education. (n.d.). Masterplan 4. Retrieved from https://ictconnection.moe.edu.sg/masterplan-4

Nasi, G., Cucciniello, M., \& Guerrazzi, C. (2015). The role of mobile technologies in health care processes: The case of cancer supportive care. Journal of Medical Internet Research, 17(2), e26.

Norris, C. A., \& Soloway, E. (2015). Mobile technology in 2020: Predictions and implications for K-12 education. Educational Technology, 55(1), 12-19.

North, A. S., \& Noyes, J. M. (2002). Gender influences on children's computer attitudes and cognitions. Computers in Human Behavior, 18(2), 135-150.

Perkins, D. N. (1992). Technology meets constructivism: Do they make a marriage? Educational Technology, 31(5), 18-23.

Qiang, C. Z., Kuek, S. C., Dymond, A., \& Esselaar, S. (2012). Mobile applications for agriculture and rural development. Washington, DC: World Bank. Retrieved from https://openknowledge.worldbank.org/handle/10986/21892

Quinn, C. (2000). mLearning: Mobile, wireless, in-your-pocket learning. Retrieved from http://www.linezine.com/2.1/features/cqmmwiyp.htm

Savenye, W. C., Davidson, G. V., \& Orr, K. B. (1992). Effects of an educational computing course on preservice teachers' attitudes and anxiety towards computers. Journal of Computing in Childhood Education, 3(1), 31-41.

Schmid, E. C. (2008). Potential pedagogical benefits and drawbacks of multimedia use in the English language classroom equipped with interactive whiteboard technology. Computers \& Education, 51(4), 1553-1568.

Selwyn, N. (2007). The use of computer technology in university teaching and learning: A critical perspective. Journal of Computer Assisted Learning, 23(2), 83-94. 
Shoffner, M. (2009). Personal attitudes and technology: Implications for preservice teacher reflective practice. Teacher Education Quarterly, 36(2), 143-161.

Simonson, M. (1995). Instructional technology and attitude change. In G. J. Aglin (Ed.), Instructional technology: Past, present, and future (pp. 365-373). Eaglewood, CO: Libraries Unlimited.

Stevens, D., \& Kitchenham, A. (2011). An analysis of mobile learning in education, business, and medicine. In A. Kitchenham (Ed.), Models for interdisciplinary mobile learning: Delivering information to students (pp. 1-25). Hershey, PA: IGI Global.

Stoerger, S. (2013). Becoming a digital nomad: Transforming education through mobile devices. In Z. L. Berge \& L. Y. Muilenberg (Eds.), Handbook of mobile learning (pp. 1114-1134). New York, NY: Routledge.

Stolle, E. J. P. (2007). Secondary content area teachers speak about literacy and technology: Tensions, complexities, conceptualizations, and practices (Doctoral dissertation). Retrieved from PQDT Open database. (UMI No. 3258046)

Sung, Y., Chang, K., \& Liu, T. (2016). The effects of integrating mobile devices with teaching and learning on students' learning performance: A meta-analysis and research synthesis. Computers \& Education, 94, 252-275.

Sutherland, R., Armstrong, V., Barnes, S., Brawn, R., Breeze, N., Gall, M., . . John, P. (2004). Transforming teaching and learning: Embedding ICT into everyday classroom practices. Journal of Computer Assisted Learning, 20(6), 413-425.

Swallow, M. J. C. (2017). The influence of technology on teaching practices at a Catholic school. Journal of Catholic Education, 20(2), 154-176.

Teo, T. (2008). Pre-service teachers' attitudes toward computer use: A Singapore survey. Australasian Journal of Educational Technology, 24(4), 413-424.

Teo, T. (2012a). Examining the intention to use technology among pre-service teachers: An integration of the technology acceptance model and theory of planned behavior. Interactive Learning Environments, 20(1), 3-18.

Teo, T. (2012b). Proposing a model to explain teachers' intention to use technology: Identifying constructs and formulating hypotheses. International Journal of Information and Communication Technology Education, 8(3), 22-27.

Teo, T., Fan, X., \& Du, J. (2015). Technology acceptance among pre-service teachers: Does gender matter? Australasian Journal of Educational Technology, 31(3), 235-251.

Tiwari, R., Buse, S., \& Herstatt, C. (2006). Mobile banking as business strategy: Impact of mobile technologies on customer behaviour and its implications for banks. In 
PICMET Conference: Technology management for the global future: Istanbul, Turkey, 8-13 July 2006, Volume 4 (pp. 1935-1946).

UNESCO. (2012). Turning on mobile learning: Global themes. Retrieved from http://unesdoc.unesco.org/images/0021/002164/216451E.pdf

Venkatesh, V., \& Bala, H. (2008). Technology acceptance model 3 and a research agenda on interventions. Decision Sciences, 39(2), 273-315.

Venkatesh, V., \& Morris, M. G. (2000). Why don't men ever stop to ask for directions? Gender, social influence, and their role in technology acceptance and usage behavior. MIS Quarterly, 24(1), 115-139.

Wang, Y., Wu, M., \& Wang, H. (2009). Investigating the determinants and age and gender differences in the acceptance of mobile learning. British Journal of Educational Technology, 40(1), 92-118.

We Are Social. (2018, January 29). Digital in 2018 in Southeast Asia Part 2 - South-East. Retrieved from https://www.slideshare.net/wearesocial/digital-in-2018-in-southeastasia-part-2-southeast-86866464

Yaghi, H. M. (1997). Pre-university students' attitudes toward computers: An international perspective. Journal of Educational Computing Research, 16(3), 237-249.

Yildirim, S. (2000). Effects of an educational computing course on preservice and inservice teachers: A discussion and analysis of attitudes and use. Journal of Research on Computing in Education, 32(4), 479-495.

Yildirim, S., \& Kiraz, E. (1999). Obstacles in integrating online communications tools into preservice teacher education: A case study. Journal of Computing in Teacher Education, 15(3), 23-28.

Zielezinski, M. B. (2016, May 19). What a decade of education research tells us about technology in the hands of underserved students. Retrieved from https://www.edsurge.com/news/2016-05-19-what-a-decade-of-education-researchtells-us-about-technology-in-the-hands-of-underserved-students 


\section{Appendix}

Technology Acceptance Survey

Disclaimer: This survey is solely based on voluntary basis and participants may choose to withdraw anytime.

This survey is part of a study on how mobile technology is being accepted by [institute withheld] students who are going for their teaching practicum. This survey is for persons who are 18 years of age and above. Please ensure you complete the survey only if you are 18 and above.

Definition: For the purposes of this survey, the term "mobile devices" refers to laptops, phones, iPads, notebooks/tablet computers, and handheld readers.

Thank you for your participation in this survey.

1. Gender

Male

Female

2. Age

3. Academic Subject 1

4. Academic Subject 2

5. Email Address 
6. Last 4 digits of your personal phone number. (e.g. 7536)

7. I plan to use mobile devices as part of my classroom practice.

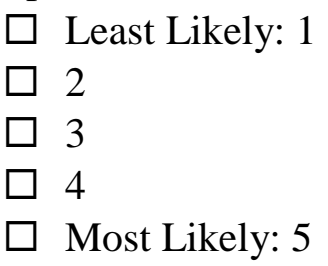

Please evaluate each of the following statements based upon the scale listed below.

( 1 = Strongly Agree, 2 = Agree, $3=$ Neither Agree nor Disagree, $4=$ Disagree, $5=$ Strongly Disagree)

8. Using mobile devices can help to improve my teaching in the classroom.
$\square 1$
$\square 2$
$\square 3$
$\square 4$
$\square 5$

9. Using mobile devices can help to improve my productivity in the classroom.
$\square 1$
$\square 2$
$\square 3$
$\square 4$
$\square 5$

10. Using mobile devices can help to enhance my effectiveness as a professional.
$\square 1$
$\square 2$
$\square 3$
$\square 4$
$\square 5$

11. I think that mobile device is going to be useful in my teaching.
$\square 1$
$\square 2$
3 
12. I think I can get mobile devices to do what I want them to do.
$\square 1$
$\square 2$
$\square 3$
$\square 4$
$\square 5$

13. I find it easy to use mobile devices in my personal life.
$\square 1$
$\square 2$
$\square 3$
$\square 4$
$\square 5$

14. I think it will be easy to use mobile devices in my professional life.
$\square 1$
$\square 2$
$\square 3$
$\square 4$
$\square 5$

15. It is easy for me to become skilful at using mobile devices.
$\square 1$
$\square 2$
$\square 3$
$\square 4$
$\square 5$

16. People who are important to me personally might affect the use of mobile devices in classroom.
$\square 1$
$\square 2$
$\square 3$
$\square 4$
$\square 5$ 
17. People who influence me professionally might affect the use of mobile devices in the classroom.
$\square 1$
$\square 2$
$\square 3$
$\square 4$
$\square 5$

18. I plan to have access to mobile devices I need for classroom use.
$\square 1$
$\square 2$
$\square 3$
$\square 4$
$\square 5$

19. I plan to have access to mobile devices I need for classroom use.
$\square 1$
$\square 2$
$\square 3$
$\square 4$
$\square 5$

20. Assuming I have access and permission to use mobile devices in the classroom, I intend to use them.
$\square 1$
$\square 2$
$\square 3$
$\square 4$
$\square 5$

21. If you plan to use mobile technology in your classroom practice, how do you intend to use it for teaching and learning? (Please be as detailed as possible, thank you!) 


\section{FIGURE CAPTION.}

Figure 1. The Technology Acceptance Model. Adapted from Davis et al. (1989) and Teo (2012b). 